\title{
Association between Serum Zinc Level and Cutaneous Viral Warts: A Case Control Study
}

\author{
Ranjit $\mathbf{A}^{1}$, Rajbhandari $\mathrm{SL}^{2}$, Gautam N ${ }^{3}$, Poudyal $\mathrm{Y}^{4}$ \\ Department of Dermatology: ${ }^{1}$ Gandaki Medical College, Pokhara, ${ }^{2}$ NAIHS College of Medicine, Kathmandu, \\ ${ }^{3}$ Department of Biochemistry, Universal College of Medical Sciences Teaching Hospital, Bhairahawa, ${ }^{4}$ Sarnath Skin \\ Centre, Bhairahawa
}

\begin{abstract}
Introduction: Cutaneous viral warts are one of the common skin disorders in general population which can affect any age group and any gender in any country and pose a significant health problem. A possible association with zinc has been suggested in previous studies. Zinc is known to be required for efficient functioning of immune system.

Objective: To find out the association between serum zinc level and cutaneous viral warts.

Materials and Methods: In this case-control study, total of hundred patients were enrolled. Among them 50 (males 27 , females - 23) with cutaneous viral warts were taken as cases and 50 (males -25 , females - 25) healthy individuals were taken as controls after matching the age and sex. The patients were selected from Dermatology outpatient Department of Universal College of Medical Sciences Teaching Hospital, Bhairahawa, Nepal. The serum zinc level was measured using spectrophotometry principle.

Results: The mean serum zinc level in the cases and controls were $80.50 \pm 37.24 \mu \mathrm{g} / \mathrm{dl}$ and $104.31 \pm 25.31 \mu \mathrm{g} / \mathrm{dl}$ respectively. Significant difference in serum zinc level was observed between cases and controls $(p=0.0001)$. There was a strong association between low serum zinc level and cutaneous viral warts ( $O R=7.37 ; 95 \% \mathrm{Cl}=1.98-27.31 ; p=0.0028)$.

Conclusion: Serum zinc level in patients with cutaneous viral warts was significantly low as compared to the healthy controls.
\end{abstract}

Key words: Immune system; micronutrients; papillomaviridae; warts; zinc

\section{Introduction}

W arts are benign tumors of the skin and mucosa caused by Human papilloma viruses (HPVs) leading to a slow and focal expansion of squamous epithelial cells. ${ }^{1}$ It is most commonly seen in school age children and young adults, though can occur at any age. In cutaneous warts, keratinocytes are infected by HPVs and are clinically visible as well defined hyperkeratotic protusions. Cutaneous warts can present as common warts, plane warts, plantar warts, periungual warts, filiform and digitate warts, butchers' warts, epidermoid plantar cysts and pigmented warts. ${ }^{2}$

Humoral immunity has a role in eliminating primary infections with HPVs but cell mediated immunity (CMI)

\section{Address of Correspondence:}

Dr. Annu Ranjit

Lecturer

Department of Dermatology, Venereology and Leprology

Gandaki Medical College, Pokhara.

E-mail: annu.ranjit@gmail.com has a key role in regression of the warts. ${ }^{2,3}$ The severity of warts as well as the risk of malignancy increases in persistent disorders of CMI. ${ }^{2}$

Zinc is an essential micronutrient having wide spectrum of activities. ${ }^{4}$ Foods like meat, eggs, shellfish, oyster, legumes, nuts, whole grain and green leafy vegetables are considered to be rich sources of zinc. ${ }^{4,5}$

Submitted: $30^{\text {th }}$ October 2018

Accepted: $15^{\text {th }}$ January 2019

Published: $31^{\text {st }}$ March 2019

\section{How to cite this article}

Ranjit A, Rajbhandari SL, Gautam N, Poudyal Y. Association between serum zinc level and cutaneous viral warts: a case control study. Nepal Journal of Dermatology, Venereology and Leprology. 2019;17(1):17-21. doi: http://dx.doi.org/10.3126/ njdvl.v17i1.23153

\section{(c) (i)}

Licensed under CC BY 4.0 International License which permits use, distribution and reproduction in any medium, provided the original work is properly cited. 
Adequate zinc intake helps in proper functioning of the immune system. Zinc deficiency adversely affects the immune function especially, T cell functions. ${ }^{6}$ Zinc has been used effectively in the treatment of various dermatological conditions including viral warts. ${ }^{4}$

Since zinc plays a significant role in clearance of warts, in this study we measured the serum zinc level in patients with cutaneous viral warts.

\section{Materials and Methods}

This case control study was conducted in Department of Dermatology, Universal College of Medical SciencesTeaching Hospital (UCMSTH), Bhairahawa, Nepal in collaboration with Department of Biochemistry from May 2015 to July 2016. Institutional review board of UCMSTH approved the study.

All patients with cutaneous viral warts attending Dermatology OPD of UCMSTH, Bhairahawa, Nepal, without any other dermatological diseases were included in this study.Patients/guardians who are not willing to participate in the study, patients who were on zinc supplementation and those with chronic diarrhea, acrodermatitis enteropathica and other systemic and dermatological diseases were excluded.

Fifty patients with cutaneous viral warts meeting the inclusion criteria were enrolled. Consecutive sampling technique was used. Fifty healthy individuals were taken as controls after age and sex matching. Informed written consent was taken.

Medical interview with proforma documentation, which included details of the patient, examination findings and serum zinc value, was done. Serum zinc level estimation was done by Nitro-PAPS methods using Sigma Aldrich Kit. The normal range of serum zinc level was considered 61-120 $\mu \mathrm{g} / \mathrm{dl}$.
The data were fed in the Microsoft Excel and analyzed by Statistical Package for Social Service (SPSS)-IBM 20. Descriptive data were expressed in mean $\pm S D$ along with frequency table. Means of continuous variables were compared by using the two-tailed independent student's t-test and qualitative variables were compared by using chi-square test. The correlations were computed by Pearson's correlation. The p-value of $\leq 0.05$ was considered to be statistically significant.

\section{Results}

Demographic data of the studied population are shown in Table 1 . The mean age of the cases and controls were $21.48 \pm 9.87$ and $22.64 \pm 9.29$ years respectively. Forty patients had $\leq 20$ lesions and 22 patients had lesions on the multiple sites. The most common type of cutaneous wart encountered was verruca vulgaris and duration of the disease was $\leq 30$ months in $76 \%$ cases. Only five patients had recurrent disease (Table 2).

Sixteen patients (32\%) had decreased serum zinc level and one (2\%) patient had increased serum zinc level. Among the control, three (6\%) of them had decreased serum zinc level. There was statistically significant difference in distribution of serum zinc level among the cases and controls. ( $p=0.004)$ (Figure 1).

The difference of mean serum zinc levels in cases $(80.50 \pm 37.24 \mu \mathrm{g} / \mathrm{dl})$ and controls $(104.31 \pm 25.31 \mu \mathrm{g} /$ dl) was statistically significant $(p=0.0001)$. Strong association between low serum zinc level and cutaneous viral warts was seen with Odds Ratio (OR)of 7.37 (95\% Cl=1.98 - 27.31; $\mathrm{p}=0.0028)$.

Serum zinc level was negatively correlated with number of lesions $(r=-0.333, p=0.001)$, largest size of the lesion $(r=-0.207, p=0.039)$, site of the lesions ( $r$ $=-0.304, p=0.002)$ and recurrence of the disease $(r=$ $-3.31, p=0.001$ ) (Table 3).

Table 1: Demographic Data of Cases and Controls.

\begin{tabular}{|c|c|c|c|}
\hline Demographic features & $\begin{array}{c}\text { Cases } \\
n=50(\%)\end{array}$ & $\begin{array}{l}\text { Controls } \\
n=50(\%)\end{array}$ & $p$-value \\
\hline \multicolumn{3}{|l|}{ Sex } & \multirow{3}{*}{0.576} \\
\hline Male & $27(54 \%)$ & $25(50 \%)$ & \\
\hline Female & $23(46 \%)$ & $25(50 \%)$ & \\
\hline \multicolumn{3}{|l|}{ Age groups } & \multirow{6}{*}{0.691} \\
\hline $0-10$ & $5(10 \%)$ & $2(4 \%)$ & \\
\hline $11-20$ & $21(42 \%)$ & $21(42 \%)$ & \\
\hline $21-30$ & $17(34 \%)$ & $20(40 \%)$ & \\
\hline $31-40$ & $5(10 \%)$ & $5(10 \%)$ & \\
\hline $41-50$ & $2(4 \%)$ & $2(4 \%)$ & \\
\hline
\end{tabular}


Table 2: Characteristics of Patients with Wart $(n=50)$.

\begin{tabular}{|l|c|}
\hline Characteristics & $\mathbf{n}(\%)$ \\
\hline $0-10$ & $21(42 \%)$ \\
\hline $11-20$ & $19(38 \%)$ \\
\hline $21-30$ & $10(20 \%)$ \\
\hline Sites & $10(20 \%)$ \\
\hline Head \& Neck & $11(22 \%)$ \\
\hline Upper limb & $0(0 \%)$ \\
\hline Trunk & $7(14 \%)$ \\
\hline Lower limb & $22(44 \%)$ \\
\hline Multiple & \\
\hline Duration (months) & $38(76 \%)$ \\
\hline $1-30$ & $10(20 \%)$ \\
\hline $31-60$ & $1(2 \%)$ \\
\hline $61-90$ & $1(2 \%)$ \\
\hline $91-120$ & \\
\hline Recurrence & $5(10 \%)$ \\
\hline Yes & $45(90 \%)$ \\
\hline No & \\
\hline Types of cutaneous viral warts & $27(54 \%)$ \\
\hline Verruca vulgaris & $13(26 \%)$ \\
\hline Verruca plana & $4(8 \%)$ \\
\hline Periungal warts & $6(12 \%)$ \\
\hline Palmoplantar warts & \\
\hline
\end{tabular}

Table 3: Pearson's Correlation of Serum Zinc with Study Variables.

\begin{tabular}{|c|c|c|c|c|c|c|c|c|c|}
\hline \multirow{2}{*}{\multicolumn{2}{|c|}{$\begin{array}{l}\text { Study } \\
\text { Variable }\end{array}$}} & \multirow{3}{*}{$\begin{array}{c}\text { Age } \\
\text { (years) }\end{array}$} & \multirow{3}{*}{$\begin{array}{c}\text { Sex } \\
-0.075 \\
\end{array}$} & \multirow{3}{*}{$\begin{array}{c}\begin{array}{c}\text { Number Of } \\
\text { Lesions }\end{array} \\
-0.333^{* *}\end{array}$} & \multicolumn{2}{|c|}{ Size $(\mathrm{cm})$} & \multirow{2}{*}{ Site } & \multirow{2}{*}{$\begin{array}{l}\text { Duration } \\
\text { (Months) }\end{array}$} & \multirow{2}{*}{ Recurrence } \\
\hline & & & & & $S$ & L & & & \\
\hline \multirow{2}{*}{$\begin{array}{l}\text { Zinc } \\
(\mu \mathrm{g} / \mathrm{dl})\end{array}$} & $(r)$ & & & & -0.074 & $-0.207^{*}$ & $-0.304^{* *}$ & -0.064 & $-3.31 * *$ \\
\hline & $p$-value & 0.633 & 0.458 & 0.001 & 0.464 & 0.039 & 0.002 & 0.525 & 0.001 \\
\hline
\end{tabular}

Note $-S$ - smallest, L - largest; * - significant, ** - highly significant

Frequency (\%) distribution of Zinc Level in Cases \& Controls

cases \% : control \%

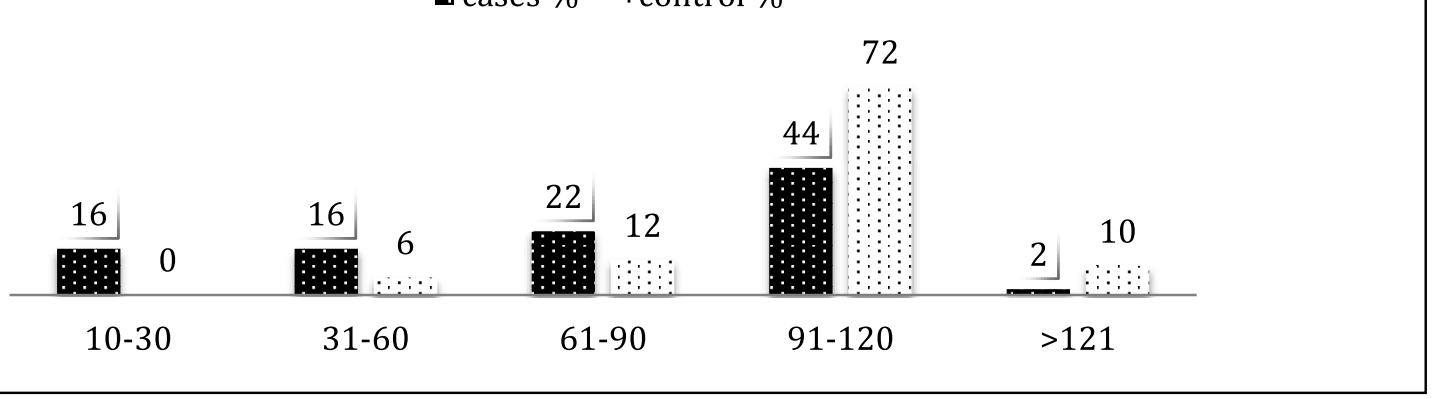

Figure 1: Bar Diagram Showing Frequency (\%) Distribution of Serum Zinc Level in Cases and Controls.

\section{Discussion}

Cutaneous viral warts are one of the common conditions presenting to the Dermatology OPD. In a study conducted at a tertiary care hospital in Nepal in the Department of Dermatology from 2014 to 2015, out of 5398 pediatric patients, 1326 had infectious dermatoses. Among them, 147 patients had viral infections and wart was seen in 94 patients. ${ }^{7}$ In another study conducted by Shrestha $\mathrm{R}$ et al in a tertiary center 
in Nepal, out of 4795 patients, 1086 (22.64\%) patients were having skin disorder and $14.12 \%$ of them had viral infection. ${ }^{8}$

Shrestha R and colleague conducted a study to see the pattern of skin diseases in rural area of Nepal and they found that the frequency of viral infection was $2.84 \%{ }^{9}$ Sula B et al observed the prevalence of viral warts to be $6.6 \%$ among primary school children in Turkey. ${ }^{10}$ In a study conducted by Van Haleen F.M et al in a primary school children in Netherland, 33\% of the children had wart. $^{11}$

In the present study, maximum numbers of cases were in the age groups $11-20$ years (42\%) followed by $21-30$ years (34\%). In a similar study conducted by Raza $\mathrm{N}$ and colleague, maximum frequency distribution of cases were in the age group $21-30$ years (40\%). ${ }^{12}$ The highest frequency observed in these age groups might suggest their aesthetic concern as well as greater environmental exposure to HPV.

In our study, it was seen that frequency distribution of cutaneous viral warts is more among the males (54\%) than in females (46\%), similar to the findings of other authors. ${ }^{12,13}$ The male predominance noted in the present study reflects our male dominant society, where females are mainly involved in household works with lack of awareness.

In this study, 29 patients had more than 10 lesions on their body. Number of lesions can be used as a measure to assess the severity of viral warts. In a study conducted by Wilson JD et al they have found that number of lesions is the best predictor of time to clearance of warts - fewer warts results in earlier clearance. ${ }^{14}$

A negative correlation between serum zinc level and number of lesions ( $r=-0.333, p=0.001$ ) was found in our study. Our result is in concordance with findings from previous study conducted by Naseri $\mathrm{M}$ et al. ${ }^{13}$

In our study, $44 \%$ patients had lesions at multiple sites and $22 \%$ of them had lesions over the upper limbs which was in contrast to the finding of Naseri $\mathrm{M}$ et al, where most of the lesions (50\%) were located in upper limbs followed by warts in multiple sites like head, neck and limbs (20\%). ${ }^{13}$ Face was the most commonly affected site in a study done by Raza $\mathrm{N}$ and colleague. ${ }^{12}$ Also a statistically significant negative correlation was seen in our study between serum zinc level and sites of the lesions $(r=-0.304, p=0.002)$, which indicates that serum zinc level is reduced if multiple sites are involved.

This study demonstrated no significant correlation between serum zinc concentration and duration of the disease $(r=-0.069, p=0.525)$. Naseri $M$ et al in their study, stated similar finding. ${ }^{13}$ Pruvost $C$ et al. observed that prevalence of warts increases with duration of immunosuppression. ${ }^{15}$

In the present study, there was a negative correlation between serum zinc concentration and recurrence of the cutaneous viral warts $(r=-3.31, p=0.001)$ suggesting that patients with recurrent disease tend to have a decreased serum zinc level.

Our study showed statistically significant difference in serum zinc level among the cases $(80.50 \pm 37.24 \mu \mathrm{g} / \mathrm{dl})$ and controls $(105.31 \pm 25.31 \mu \mathrm{g} / \mathrm{dl})$ withp-value 0.0001 which is similar to the findings of studies done by Raza $\mathrm{N}$ and colleague and Al-Gurairi FT et al. ${ }^{12,16}$ Sadighha $A$, Naseri $M$ et al and Yaghoobi $R$ et al observed no significant difference in serum zinc concentration between the cases and controls. ${ }^{13,17,18}$

In a developing nation like ours, dietary factors, malabsorption, hookworm infestations play major role in zinc deficiency. In a place with hot tropical climate considerable loss of zinc can occur through sweating. ${ }^{19}$

Cutaneous viral warts are common and posses a significant aesthetic problem to the patient. Moreover, the interplay between cutaneous viral warts and zinc deficiency might have a crucial role in pathogenesis and clearance of viral warts.

Our study has a limitation of being a single centered study.

\section{Conclusion}

The present study showed that serum zinc level is significantly low in patients with cutaneous viral warts compared to the healthy control. Serum zinc level is inversely related to number of lesions, largest size of the lesion, site of the lesions and recurrence of the disease. Further, a multicentric study with larger sample size and therapeutic interventional trial can be conducted.

Financial disclosure: None.

Conflict of interest to disclosure: The principal author has not taken any part in the editorial decision. 


\section{References}

1. Elliot J. Androphy DRL. Warts. In: Klaus Wolff LAG, Stephen I. Katz, Barbara A. Gilchrest, Amy S. Paller, David J. Leffell, editor. Fitzpatrick's Dermatology in General Medicine. 7th ed. United States: The McGraw Hill Companies.Inc; 2008. p. 1914-23.

2. Sterling JC. Virus Infections. In: Christopher E. M. Griffiths, Jonathan Barker, Tanya Bleiker, Robert Chalmers, Daniel Creamer. Rook's Textbook of Dermatology. 9th ed. London: Blackwell Publishing Ltd.; 2016. p. 25.43-58.

3. Stanley M, Coleman N, Chambers M. The host response to lesions induced by human papillomavirus. Ciba Found Symp.1994;187:2132.

4. Gupta M, Mahajan VK, Mehta KS, Chauhan PS. Zinc therapy in dermatology: a review. Dermatology research and practice. 2014;2014:709152. https://doi.org/10.1155/2014/709152

5. Golden PE, Golden MHN. Plasma zinc, rate of weight gain, and the energy cost of tissue deposition in children recovering from severe malnutrition on a cow's milk or soya-protein based diet. Am J Clin Nutr.1981; 34:892-9. https:// doi.org/10.1093/ajcn/34.5.892

6. Prasad AS. Clinical, immunological, antiinflammatory and antioxidant roles of zinc. Exp Gerontol.2008; 43: 370-7. https://doi. org/10.1016/j.exger.2007.10.013

7. Poudyal Y, Ranjit A, Pathak S, Chaudhary N. Pattern of Pediatric Dermatoses in a Tertiary Care Hospital of Western Nepal. Dermatology Research and Practice.2016; 2016(August 2015):1-6.https:// doi.org/10.1155/2016/6306404

8. Shrestha R, Shrestha D, Dhakal AK, Shakya A, Shah SC, Shakya H. Spectrum of pediatric dermatoses in tertiary care center in Nepal. Nepal Med Coll J.2012;14(2):146-8

9. Shrestha R, Kayastha BMM. Pattern of Skin diseases in a rural area of Nepal. Postgraduate Medical Journal of NAMS.2012;12(2):41-4.
10. Sula B, Uçmak D, Saka G, Akdeniz S. Prevalence of skin disorders among primary school children in Diyarbakir, Turkey. Arch Argent Pediatr.2014;112(5):434-8.

11. Van Haalen, F. M., Bruggink, S. C., Gussekloo, J., Assendelft, W. J. J., \& Eekhof, J. A. H. (2009). Warts in primary schoolchildren: prevalence and relation with environmental factors. British Journal of Dermatology, 161(1), 148-52. https:// doi.org/10.1111/j.1365-2133.2009.09160.x

12. Raza N, Khan DA. Zinc Deficiency in Patients with Persistent Viral Warts. Journal of the College of Physicians and Surgeons Pakistan.2010;20(2):83-6.

13. Naseri M, Shahbaz S, Handjani F, Ghariheh A. Serum zinc levels in patients with multiple warts. Journal of Pakistan Association of Dermatologists.2009;19:4-8.

14. Wilson JD, Brown CB, Walker PP. Factors involved in clearance of genital warts. Int J STD AIDS.2001;12:789-92. https://doi. org/10.1258/0956462011924407

15. Pruvost C, Penso-Assathiany D, Bachot $\mathrm{N}$ et al. Risk factors for cutaneous wart onset in transplant recipients. Ann Dermatol Venereol.2002;129:291-3.

16. Al-Gurairi FT, Al-Waiz $M$, Sharquie KE. Oral zinc sulphate in the treatment of recalcitrant viral warts: randomized placebocontrolled clinical trial. BritishJournal of Dermatology.2002;146:423-31.https://doi. org/10.1046/j.1365-2133.2002.04617.x

17. Sadighha A. Oral zinc sulphate in recalcitrant multiple viral warts: a pilot study. European Academy of Dermatology and Venereology. 2009;23:715-6.https://doi.org/10.1111/j.14683083.2009.03169.x

18. Yaghoobi R, Sadighha A, Baktash D. Evaluation of oral zinc sulfate effect on recalcitrant multiple viral warts: A randomized placebo-controlled clinical trial. J Am Acad Dermatol. 2009;60(4):7068.https://doi.org/10.1016/j.jaad.2008.09.010

19. Prasad AS. Zinc in human health: effect of zinc on immune cells. Mol Med.2008;14:353-7https:// doi.org/10.2119/2008-00033.Prasad 